\title{
EVALUASI PENERAPAN ISO 9001:2008 DI LINGKUNGAN UIN SYARIF HIDAYATULLAH JAKARTA
}

\author{
Amirudin \\ Fakultas Ilmu Dakwah dan Ilmu Komunikasi UIN Syarif Hidayatullah Jakarta
}

\begin{abstract}
Evaluation of ISO 9001: 2008 Implementation in UIN Syarif Hidayatullah Jakarta. The aim of this research is to evaluate the ISO 9001: 2008 implementation in UIN Syarif Hidayatullah Jakarta. The assumption that used on this research is the ISO: 9001: 2008 implementation still can't give an impact to service quality. This research used the survey technique such as quetionnaire. The analysis method that used is descriptive analysis, inferential analysis, and question analysis. The result from this research is there were influences of ISO 9001: 2008 implementation on employee performance at UIN Syarif Hidayatullah Jakarta, and also as average from eight dimensions on ISO 9001: 2008 had a good category. In some category, students still non satisfied on employee performance.
\end{abstract}

Keywords: ISO 9001: 2008, quality management, satisfaction, employee performance

\begin{abstract}
Abstrak. Evaluasi Penerapan ISO 9001: 2008 di Lingkungan UIN Syarif Hidayatullah Jakarta. Penelitian ini untuk menelaah penerapan ISO 9001:2008 yang sedang berlaku di UIN Syarif Hidayatullah Jakarta. Asumsi yang dipergunakan dalam penelitian ini ialah penerapan ISO 9001:2008 di UIN Syarif Hidayatullah Jakarta belum menyentuh substansi dari mutu pelayanan. Penelitian ini menggunakan teknik survei yang berupa angket. Metode analisis yang digunakan dalam penelitian ini adalah teknik analisis statistik deskriptif, analisis statistik inferensia dan analisis butir soal. Dari hasil penelitian ini secara umum terdapat pengaruh penerapan ISO 9001:2008 terhadap kinerja karyawan di lingkungan UIN Syarif Hidayatullah Jakarta dan nilai rata-rata 8 (delapan) dimensi ISO 9001:2008 memiliki kategori baik. Selain itu, dalam beberapa hal mahasiswa kurang puas terhadap kinerja karyawan.
\end{abstract}

Kata Kunci: ISO 9001:2008, manajemen mutu, kepuasan, kinerja karyawan. 


\section{PENDAHULUAN}

Persaingan dan perkembangan perguruan tinggi saat ini melaju pesat, seiringnya kesadaran masyarakat akan pentingnya pendidikan semakin tinggi. Pendidikan saat ini sudah menjadi kebutuhan pokok setiap orang. Mengingat pentingnya pendidikan tersebut, maka persaingan antar perguruan tinggi semakin gencar, baik sesama yang berlabel negeri maupun yang berlabel swasta, mau tidak mau semua pihak dituntut untuk mempersiapkan diri untuk mampu bertahan (survive) dalam menghadapi kondisi tersebut.

Seiring dengan kondisi ini, standarisasi manajemen telah menjadi isu utama lebih khusus lagi standarisasi tentang standarisasi sistem manajemen mutu. Untuk itu, suatu lembaga baik pemerintah maupun swasta perlu menyiapkan kerangka sistem mutu lembaganya kearah yang diinginkan sesuai dengan sasaran atau tujuan akhir yang ditetapkan oleh lembaga tersebut, dalam pengertian bahwa tujuan atau sasaran mutu dari suatu lembaga mampu mencapai kesesuaian dengan keinginan yang diharapkan dari pelanggan atau mitra kerja lembaga tersebut.

Menanggapi isu tersebut diatas, salahsatu standar sistem manajemen mutu yang telah berkembang di negara maju dan bahkan di negara-negara berkembang adalah ISO 9001:2008. Standar ini merupakan sarana atau sebagai alat untuk dapat mencapai tujuan mutu dalam menerapkan Total Quality Control yang diharapkan mampu menjawab perkembangan globalisasi ini dimana tujuan akhirnya adalah mencapai efektifitas dan efisiensi suatu organisasi. Standar ini merupakan salah satu standar yang diakui secara internasional, yang selanjutnya sudah diadopsi di seluruh negara.

ISO 9001:2008 adalah suatu standar Internasional untuk sistem manajemen mutu, yang menetapkan persyaratan-persyaratan dan rekomendasi untuk desain dan penilaian dari suatu sistem manajemen mutu yang bertujuan untuk menjamin bahwa organisasi akan memberikan produk (barang/jasa) yang memenuhi persyaratan yang ditetapkan (PSA DEPTAN, 2002). Persyaratan-persyaratan yang ditetapkan ini dapat merupakan kebutuhan spesifik dan pelanggan, yang mana organisasi yang dikontrak ini bertanggung jawab untuk menjamin kualitas dan produk-produk tertentu, atau merupakan 
kebutuhan dari pasar tertentu, sebagaimana ditentukan oleh organisasi. ISO 9001:2008 bukan merupakan standar produk, karena tidak menyatakan persyaratan-persyaratan yang harus dipenuhi oleh produk (barang/jasa). Tidak ada kriteria penerimaan produk dalam ISO 9001:2008, sehingga kita tidak dapat menginspeksi suatu produk terhadap standar-standar produk. ISO 9001:2008 hanya merupakan standar sistem manajemen mutu. Dengan demikian apabila ada perusahaan yang mengiklankan bahwa produknya telah memenuhi standar Internasional, itu merupakan hal yang salah dan keliru, karena seyogyanya manajemen perusahaan hanya boleh menyatakan bahwa sistem manajemen mutunya telah memenuhi standar Internasional, bukan produk berstandar Internasional. Karena tidak ada kriteria pengujian produk dalam ISO 9001:2008. Walaupun demikian diharapakan suatu produk yang dihasilkan dari suatu sistem manajemen mutu internasional akan akan menjadi produk yang berkualitas dan berstandar internasional. Sistem manajemen mutu mendefinisikan bagaimana organisasi menerapkan praktek-praktek manajemen mutu secara konsisten untuk memenuhi kebutuhan pelanggan dan pasar.

\section{METODE}

ISO 9001:2008 adalah skor yang menyatakan informasi mengenai kemampuan karyawan di lingkugan UIN Syarif Hidayatullah dalam melaksanakan ISO 9001:2008. Dimana informasi mengenai ISO 9001:2008 meliputi 8 dimensi, yaitu: fokus pelanggan, kepemimpinan, partisipasi karyawan, pendekatan proses, pendekatan sistem, perbaikan terus-menerus, pendekatan faktual dalam pengambilan keputusan dan hubungan timbal balik yang menguntungkan dengan pemasok.

Kinerja karyawan adalah skor yang menyatakan informasi ukuran kinerja karyawan. Ukuran kinerja yang meliputi; kuantitas kerja, kualitas kerja, pengetahuan tentang pekerjaan, kemampuan mengemukakan pendapat, pengambilan keputusan, perencanaan kerja dan daerah organisasi kerja.

Dalam menentukan jumlah sampel menggunakan rumus rumus slovin, yaitu :

$$
n=\frac{N}{N \cdot e^{2}+1}
$$


Keterangan:

n : Jumlah sampel minimum

$\mathrm{N}$ : Jumlah Populasi

$\mathrm{e}^{2}$ : Margin kesalahan $(0,01,0,02,0,03,0,04,0,05,0,10 \mathrm{dsb})$

Dari rumus di atas, jumlah populasi sebesar 9433 orang maka jumlah sampel adalah:

$n=\frac{9433}{9433 \cdot(0.07)^{2}+1}=199,759=200$

Teknik pengambilan sampel yang digunakan adalah nonprobability sampling, dimana tidak terdapat jaminan bahwa setiap elemen dalam populasi memiliki kesempatan yang sama untuk dimasukkan ke dalam sampel penelitian. Teknik pengambilan sampel yang digunakan adalah Purposive sampling. yaitu suatu metode teknik penarikan contoh yang digunakan peneliti jika peneliti mempunyai pertimbangan-pertimbangan tertentu di dalam pengambilan contoh atau penentuan contoh untuk tujuan tertentu (Eriyanto, 2007).

Alasan penggunaan metode purposive sampling adalah pertma, jumlah responden relatif besar. Kedua, mudah dalam memperoleh obyek penelitian. Ketiga, tempat pengambilan obyek terdapat pada satu tempat, sehingga memudahkan peneliti dalam pengambilan contoh. Keempat, responden relatif homogen

Jenis data yang digunakan dalam penelitian ini berupa data primer dan data sekunder. Data primer untuk mengetahui kepuasan layanan yang diberikan oleh karyawan dan data sekunder untuk mengetahui jumlah mahasiswa. Pertanyaan dalam kuesioner pada penelitian ini menggunakan Skala Likert. Menurut Rangkuti (2002), skala likert digunakan dalam kuesioner dimana responden menyatakan tingkat puas atau tidak puas mengenai pertanyaan yang diajukan. Bobot dalam skala likert dibuat ke dalam 4 (empat) penilaian, yaitu :

$1=$ Sangat tidak Puas

$2=$ Tidak Puas

$3=$ Puas

4 = Sangat Puas 
Teknik pengumpulan data yang dilakukan dalam penelitian ini yaitu survei menggunakan angket atau kuesioner. Angket merupakan suatu teknik atau cara pengumpulan data secara tidak langsung (peneliti tidak langsung bertanya jawab dengan responden) yang berisi mengenai sejumlah pernyataan yang harus dijawab atau direspon oleh responden, selain itu responden mengetahui informasi yang diminta.

Dalam menentukan penelitian terdapat lima bentuk skala sikap yang perlu diketahui yaitu: skala likert, skala guttman, skala simantict differential, rating scale, dan skala thurstone (Riduwan dan Akdon, 2005). Karena dalam penelitian ini hanya akan mengukur pendapat, persepsi seseorang terhadap gejala sosial yang diteliti maka dalam penelitian ini menggunakan pengukuran skala sikap model Likert untuk mengetahui pengaruh penerapan ISO 9001:2008 terhadap kinerja karyawan. Oleh karena itu dibuatlah angket untuk diberikan kepada responden yaitu: angket ISO 9001:2008, dan angket kinerja karyawan.

Teknik analisis data yang diterapkan agar tujuan penelitian dapat tercapai, yaitu: analisis deskriptif dan analisis inferensia. Dalam analisis deskripstif data yang terkumpul disajikan ke dalam bentuk tabel atau grafik atau bagan (disesuaikan dengan keperluan penelitian) untuk memudahkan dalam mendeskripsikan data. Cara ini ditujukan untuk menggambarkan datadata yang diperoleh sesuai dengan kondisi apa adanya tanpa melakukan manipulasi data apapun.

Analisis inferensia ini dilakukan untuk mengetahui apakah ada pengaruh ISO 9001:2008 terhadap kinerja karyawan. Teknik analisis inferensia yang digunakan adalah analisis regresi linear sederhana.

Menurut Santoso (Singgih, 2009) dalam melakukan teknik analisis inferensia ini ada asumsi yang harus dipenuhi, yaitu: "a) populasi-populasi yang akan diuji berdistribusi normal, b) varians dari populasi-populasi tersebut adalah sama; dan c) sampel tidak berhubungan satu dengan yang lain". Untuk menguji apakah populasi berdistribusi normal atau tidak dalam penelitian ini menggunakan perhitungan uji Kolmogorov-Smirnov dengan bantuan SPSS versi 17.00 dengan ketentuan jika signifikansi lebih besar dari 0,05 maka sampel yang berasal dari populasi telah berdistribusi normal. Setelah distribusi data 
dinyatakan normal maka baru dilakukan perhitungan uji statistik. Pengujian statistik pada uji regresi linear sederhana dilakukan dengan ketentuan, yaitu: pertama, perbandingan nilai $\mathrm{F}_{\text {hitung }}$ dan $\mathrm{F}_{\text {tabel. }}$ Jika $\mathrm{F}_{\text {hitung }}$ lebih besar dari $\mathrm{F}_{\text {tabel }}$ maka Ho ditolak dan sebaliknya jika $\mathrm{F}_{\text {hitung }}$ lebih kecil dari $\mathrm{F}_{\text {tabel }}$ maka Ho diterima. Kedua, berdasarkan angka probabilitas. Jika besarnya probabilitas (signifikansi) lebih kecil dari 0,05 maka Ho ditolak dan sebaliknya jika probabilitas (signifikansi) lebih besar dari 0,05 maka Ho diterima.

\section{PEMBAHASAN}

Variabel-variabel yang diteliti dalam penelitian ini adalah ISO 9001:2008 (X) dan Kinerja Karyawan (Y). Data penelitian yang diperoleh dari dua variabel di atas merupakan jawaban responden atas kuesioner untuk mahasiswa. Dari hasil penelitian terdapat jumlah responden sebanyak 200 mahasiswa, dengan 24 pertanyaan variabel ISO 9001:2008 (X) dan 6 pertanyaan variabel Kinerja Karyawan (Y). Rata-rata variabel ISO 9001:2008 (X) 55,73 dengan nilai terendah 24 dan nilai tertinggi 82. 55\% nilai variabel ISO 9001:2008 (X) di atas rata-rata dan sisanya sebanyak $45 \%$ di bawah rata-rata. Rata-rata variabel Kinerja Karyawan (Y) 14,34, dengan nilai terendah 6 dan nilai tertinggi 23.50\% nilai variabel Kinerja Karyawan $(\mathrm{Y})$ di atas rata-rata dan sisanya di bawah ratarata $(50 \%)$.

Teknis analisis yang digunakan dalam penelitian ini adalah statistika parametrik, dimana dalam teknik analisis ini dibutuhkan uji persyaratan analisis, salah satu uji yang dipersyaratkan adalah uji normalitas. Uji normalitas bisa dilakukan dengan melihat grafik QQ-Plot atau bisa juga dengan pengujian normalitas. Salah satu uji untuk melihat kenormalan sebuah data adalah uji Kolmogorov-Smirnov.

Dari pengolahan yang dilakukan terhadap variabel ISO 9001: 2008 terlihat bahwa data berada disekitar garis, ini menunjukkan data tersebut menyebar secara normal. Untuk lebih jelas maka peneliti melakukan uji Kolmogorov-Smirnov, dari hasil yang didapat terlihat bahwa nilai Asym.Sig (2tailed) 0.475 . jika menggunakan alpha 0,1 dan hipotesis yang digunakan dua arah (2-tailed) maka alpha menjadi 0,05. Karena nilai Asym.Sig lebih besar dari 
nilai alpha maka sebaran data untuk variabel ISO 9001:2008 menyebar secara normal.

Data kinerja karyawan memperlihatkan bahwa data berada di sekitar garis, ini menunjukkan data tersebut menyebar secara normal. Untuk lebih jelas maka peneliti melakukan uji Kolmogorov-Smirnov, terlihat bahwa nilai Asym.Sig (2-tailed) 0.093. jika menggunakan alpha 0,1 dan hipotesis yang digunakan dua arah (2-tailed) maka alpha menjadi 0,05. Karena nilai Asym.Sig lebih besar dari nilai alpha maka sebaran data untuk variabel Kinerja Karyawan (Y) menyebar secara normal. Karena uji persyaratan sudah dipenuhi maka, bisa dilanjutkan ke analisis yang selanjutnya, yaitu analisis regresi linear sederhana.

Dari hasil yang didapat memperlihatkan bahwa nilai korelasi antara variabel ISO 9001:2008 dengan Kinerja karyawan sebesar 0.775, hal ini menunjukkan bahwa ada hubungan yang tinggi antara variabel ISO 9001:2008 dengan Kinerja Karyawan. Dari output di atas juga dapat kita buat model regresi, yaitu:

$\hat{\mathrm{Y}}=1.599+0.229 \mathrm{X}$

Berdasarkan model di atas dapat didefinisikan bahwa setiap penambahan variabel ISO 9001:2008 sebesar satu satuan maka nilai Kinerja Karyawan akan bertambah sebesar 0.229. untuk mengetahui apakah model yang digunakan cukup fit dalam melakukan pendugaan maka dilakukan dengan uji ANOVA. Dari tabel ANOVA diatas terlihat bahwa nilai $F_{\text {hitung }}$ sebesar 297.861 dan nilai sig. regresi $0.000^{\text {a }}$. karena nilai Sig. Untuk model regresi tersebut lebih kecil dari alpha $(0,05)$ maka model tersebut cukup fit untuk digunakan dalam melakukan pendugaan. Dari hasil yang ada dapat terlihat juga nilai $\mathrm{R}^{2}$ sebesar 0.601, ini artinya keragaman Kinerja Karyawan yang mampu dijelaskan oleh ISO 9001:2008 sebesar 0.601 atau sebesar $60.1 \%$, adapun sisanya sebesar $39.9 \%$ keragaman Kinerja Karyawan dijelaskan oleh variabel (faktor) lain. Hasil yang didapat menunjukkan bahwa ada pengaruh yang signifikan antara ISO 9001:2008 terhadap Kinerja Karyawan.

Meskipun secara statistik telah dilakukan pengujian dan menghasilkan pengaruh yang sangat signifikan antara penerapan ISO 9001:2008 terhadap Kinerja Karyawan, namun dalam pengujian tersebut belum terlihat apakah 
penerapan ISO sudah berjalan sesuai dengan prosedur dan dapat dirasakan langsung oleh mahasiswa. Untuk menjawab pertanyaan ini maka peneliti akan peneliti akan mengkaji dengan menggunakan kategorisasi. Kategorisasi ini mengadopsi pada kategorisasi yang dibuat oleh MENPAN yang berkaitan dengan survei kepuasan layanan masyarakat (www.menpan.go.id).

Sebelum kita membahas lebih lanjut mengenai tingkat kepuasan terhadap layanan yang diberikan oleh karyawan, lebih baik jika kita meninjau kembali tentang definisi manajemen mutu. Konsep manajemen mutu dibangun berdasarkan konsep manajemen secara umum. Menurut Willy Susilo (2003) Manajemen adalah proses sistematis untuk mencapai tujuan melalui fungsi perencanaan, pelaksanaan, pemeriksaan dan tindak lanjut. Perencanaan adalah proses menetapkan apa yang ingin dicapai dan menjabarkan bagaimana cara mencapainya. Pelaksanaan adalah proses merealisasikan apa yang telah dipikirkan dan ditetapkan dalam perencanaan. Pemeriksaan adalah proses memperoleh informasi mengenai kemajuan atau tingkat efektivitas pencapaian hasil atau sasaran yang direncanakan dengan cara melakukan evaluasi. Evaluasi adalah kegiatan menilai, mengukur atau membandingkan apa yang telah dilaksanakan dan dicapai dengan apa yang seharusnya dicapai dan dilaksanakan. Tindak lanjut adalah melakukan tindakan yang diperlukan sesuai informasi dari hasil evaluasi. Apa yang dimaksud dengan mutu? Ada beberapa konsep mutu yang dapat memberikan penjelasan tentang arti mutu. Philip crosby yang dikutip oleh Willy Susilo (Willy, 2003) mendefinisikan mutu sebagai kesesuaian terhadap persyaratan.

Secara umum dan lengkap manajemen mutu dapat didefinisikan: Manajemen mutu adalah upaya sistematis mealui fungsi perencanaan, pelaksanaan, pemeriksaan atau pengendalian serta tindak lanjut terhadap semua unsur organisasi, baik internal maupun eksternal yang tercakup dalam dimensi material, metode, mesin, dana, manusia, lingkungan dan informasi untuk merealisasikan komitmen, kebijakan dan sasaran mutu yang telah ditetapkan dalam rangka memberikan kepuasan kepada pelanggan untuk masa sekarang maupun di masa depan. 
Kemudian apakah yang dimaksud dengan ISO. ISO adalah sebuah kata yang berasal dari bahasa Yunani yang berarti“sama” , hal ini mempunyai analogi yang sama dengan beberapa istilah yaitu“isoterm” yang berarti suhu yang sama, "isobar" yang berarti tekanan yang sama. Alasan dipakainya kata "ISO" adalah agar mempermudah dalam penggunaan dan mudah diteliti. Jika yang digunakan adalah singkatan. tentunya setiap Negara akan berbeda singkatannya. Jadi bisa diambil pengertian bahwa ISO hanyalah sebuah kata yang dijadikan standar cara untuk mempermudah dalam penggunaan, pemahaman.

Caspersz yang dikutip oleh Willy (Willy, 2003) menjelaskan bahwa ISO 9001 merupakan suatu standar-standar internasional untuk sistem kualitas, yang menspesifikasikan persyaratan-persyaratan dan rekomendasi untuk desain, langkah-langkah produksi dan penilaian dan suatu sistem manajemen. Dari pengertian diatas, bisa disimpulkan bahwa IS0 9001 merupakan suatu standar yang memegang peranan penting dalam bidang sistem mutu, khususnya yang membahas pengendalian langkah-langkah produksi atau pelayanan dalam lingkup produk atau jasa.

ISO 9001:2008 adalah suatu standar Internasional untuk sistem manajemen mutu, yang menetapkan persyaratan-persyaratan dan rekomendasi untuk desain dan penilaian dari suatu sistem manajemen mutu yang bertujuan untuk menjamin bahwa organisasi akan memberikan produk (barang/jasa) yang memenuhi persyaratan yang ditetapkan. Persyaratan-persyaratan yang ditetapkan ini dapat merupakan kebutuhan spesifik dan pelanggan, yang mana organisasi yang dikontrak ini bertanggungjawab untuk menjamin kualitas dan produk-produk tertentu, atau merupakan kebutuhan dari pasar tertentu, sebagaimana ditentukan oleh organisasi. ISO 9001:2008 bukan merupakan standar produk, karena tidak menyatakan persyaratan-persyaratan yang harus dipenuhi oleh produk (barang/jasa). Tidak ada kriteria penerimaan produk dalam ISO 9001:2008, sehingga kita tidak dapat menginspeksi suatu produk terhadap standar-standar produk. ISO 9001:2008 hanya merupakan standar sistem manajemen mutu. Dengan demikian apabila ada perusahaan yang mengiklankan bahwa produknya telah memenuhi standar Internasional, itu merupakan hal yang salah dan keliru, karena seyogyanya manajemen 
perusahaan hanya boleh menyatakan bahwa sistem manajemen mutunya telah memenuhi standar Internasional, bukan produk berstandar Internasional. Karena tidak ada kriteria pengujian produk dalam ISO 9001:2008. Walaupun demikian diharapakan suatu produk yang dihasilkan dari suatu sistem manajemen mutu Internasional akan akan menjadi prodak yang berkualitas dan berstandart internasional.

Berdasarkan sebaran kuesoner yang telah dilakukan, maka didapatkan hasil kepuasan mahasiswa terhadap layanan yang diberikan oleh karyawan berdasarkan delapan dimensi sebagaimana tertera pada tabel 1. Jika melihat hasil kategorisasi, maka rata-rata kepuasan mahasiswa terhadap layanan karyawan Baik semua, maka untuk lebih jelasnya akan ditelusuri kepuasan mahasiswa terhadap layanan karyawan dalam tiap butir pertanyaan.

Tabel 1. Kepuasan Mahasiswa Terhadap Layanan Karyawan

\begin{tabular}{clcc}
\hline No & Uraian & $\begin{array}{c}\text { Tingkat } \\
\text { Kepuasan }\end{array}$ & $\begin{array}{c}\text { Kategori } \\
\text { Kepuasan }\end{array}$ \\
\hline 1 & Fokus Pada Pelanggan & 2,56 & Baik \\
2 & Kepemimpinan & 2,51 & Baik \\
3 & Partisipasi Karyawan & 2,97 & Baik \\
4 & Pendekatan Proses & 2,96 & Baik \\
5 & Pendekatan sistem pada & & Baik \\
& manajemen & 2,81 & Baik \\
6 & Perbaikan kesinambungan & 2,76 & Baik \\
7 & Pendekatan fakta pada & & Baik \\
& pengambilan keputusan & 3,03 & \\
8 & Hubungan yang saling & & \\
& menguntungkan & 3,07 & \\
\hline
\end{tabular}

Sumber: Data diolah

Hasil yang didapat menunjukkan bahwa ada ketimpangan layanan yang diberikan oleh karyawan terhadap mahasiswa, di beberapa butir pertanyaan mahasiswa menganggap sangat puas terhadap layanan yang diberikan oleh karyawan, namun di sisi layanan lain mahasiswa menganggap layanan yang diberikan kurang maksimal. Pertama, terkait dengan fokus pada Pelanggan, pada dimensi ini mayoritas mahasiswa sangat puas dalam hal ketepatan waktu, namun menjadi terbalik dalam hal cepat tanggap dalam memahami masalah dan memahami keluhan pelanggan. Kedua, terkait dengan kepemimpinan. Mayoritas mahasiswa menganggap bahwa karyawan UIN Syarif Hidayatullah Jakarta memiliki pemimpin yang berkualitas. Namun kurang mampu mempengaruhi 
karyawannya sehingga kurang memotivasi karyawan. Ketiga, terkait dengan partisipasi karyawan. Mayoritas mahasiswa berasumsi bahwa karyawan yang ada di UIN Syarif Hidayatullah sangat berkompeten dan aktif dalam menjalankan tugasnya namun tidak dibarengi dengan pemahaman akan fungsi dan tugasnya. Keempat, terkait dengan pendekatan proses. Mayoritas mahasiswa menganggap bahwa karyawan tidak melaksanakan tugas sesuai prosedur padahal mahasiswa berasumsi bahwa prosedur tersebut sudah ada.

Kelima, terkait dengan pendekatan sistem pada manajemen. Mayoritas responden menganggap bahwa sistem pada manajemen sudah berjalan dengan baik, hal ini bisa dilihat dari perencanaan pekerjaan yang baik, jika melaksanakan tugas sudah tidak disuruh-suruh lagi. Keenam, terkait dengan perbaikan kesinambungan. Mayoritas mahasiswa menilai bahwa sudah tersedianya kotak saran dan dilakukannya evaluasi kinerja, namun evaluasi tersebut tidak dilakukan secara rutin. Ketujuh, terkait dengan pendekatan fakta pada pengambilan keputusan. Mayoritas mahasiswa menganggap bahwa informasi mengenai perkuliahan sudah tersedia di fakultas, namun informasi tersebut susah diperoleh. Kedelapan, terkait dengan hubungan yang saling menguntungkan. Secara umum mahasiswa kurang puas terhadap kinerja karyawan di fakultas, meskipun didukung oleh fasilitas yang memadai.

Semuel dan Zulkarnaen (2006) melakukan penelitian yang berjudul tentang Pengaruh Sistem Manajemen Mutu (SMM) ISO terhadap Kinerja Karyawan melalui Budaya Kualitas Perusahaan, dengan objek penelitian PT Otsuka Indonesia Malang. SMM ISO dilihat dari tiga dimensi, yaitu Perencanaan Sertifikasi ISO 9001, Komitmen Perusahaan, dan Penerapan Prosedur. Data penelitian diperoleh dari sampel 110 responden karyawan yang dipilih secara acak. Hasil penelitian menemukan bahwa Perencanaan Sertifikasi ISO 9001, Komitmen Perusahaan, dan Penerapan Prosedur dipersepsikan sudah sangat baik oleh karyawan dan berpengaruh positif secara signifikan terhadap Budaya Kualitas perusahaan. Selanjutnya Budaya Kualitas berpengaruh positif secara signifikan terhadap Kinerja Karyawan, namun demikian Budaya Kualitas masih dipersepsikan karyawan belum terlalu baik, dikarenakan Empowerment dan 
Involvement serta Quality Improvement Team Work belum dijalankan secara optimal.

Dharma (2007) penelitian yang mencoba melihat apakah ada pengaruh penerapan sistem manajemen mutu ISO 9001: 2000 terhadap kinerja karyawan di PT Asuransi Jasa Raharja Cabang Sumatera Utara. Penelitian ini merupakan penelitian survey. Hasil penelitian ini menunjukkan bahwa secara simultan dan parsial sistem manajemen mutu ISO 9001: 2000 berpengaruh positif dan sangat signifikan terhadap kinerja karyawan. Hal ini berarti setiap kebijakan yang dilakukan perusahaan telah sesuai dengan sistem jaminan mutu ISO 9001: 2000.

Mifriadi (2006) melakukan penelitian yang menunjukkan bahwa penerapan sistem manajemen kualitas ISO 9002 berpengaruh positif terhadap produktivitas karyawan. Sedangkan peningkatan kualitas kehidupan kerja memberi pengaruh negatif terhadap produktivitas karyawan karena terbentur masalah biaya, dimana dalam jangka pendek perusahaan harus memfokuskan untuk memenuhi kapasitas bahan baku terlebih dahulu agar dapat terus bertahan. Penerapan sistem manajemen kualitas ISO 9002 dipengaruhi oleh indikator-indikator yang bernilai positif diantaranya adalah fasilitas kerja, komunikasi, partisipasi karyawan, kebijakan mutu perusahaan, keberadaan tim pelaksana ISO dan pengendalian dokumen. Kualitas kehidupan kerja dipengaruhi oleh beberapa indikator yaitu perlakuan adil, fair dan suportif terhadap karyawan, kesempatan menggunakan kemampuan sepenuhnya untuk mewujudkan diri dan kompensasi yang cukup fair. Sementara itu produktivitas karyawan dipengaruhi oleh beberapa indikator yang berasal dari diri karyawan itu sendiri diantaranya adalah perilaku karyawan, disiplin karyawan dan kerjasama antar karyawan. Terdapat faktor eksternal yang mempengaruhi produktivitas lebih kuat dari pada faktor-faktor yang ada dalam perusahaan yaitu kualitas dan kuantitas bahan baku serta kontiniutas pasokannya

Irani dan Hadiputra (2010) dalam penelitian tentang pengaruh penerapan sistem manajemen mutu ISO 9001: 2008 di PT Telkom terhadap kinerja karyawan. Hasil penelitian ini menunjukkan bahwa secara simultan sistem manajemen mutu ISO 9001: 2008 berpengaruh positif dan sangat 
signifikan terhadap kinerja karyawan di PT Telkom. Hal ini berarti setiap kebijakan yang dilakukan perusahaan telah sesuai dengan sistem manajemen mutu ISO 9001: 2008.

Lestari (2012) dalam penelitian yang ini berupaya melihat bagaimana pengaruh penjaminan mutu terhadap kinerja. Teknik analisis yang dipergunakan ialah korelasi Pearson product-moment. Hasil yang didapat menunjukkan bahwa penerapan sistem penjaminan mutu internal dan sistem manajemen mutu ISO memiliki pengaruh bagi peningkatan kinerja.

Silaban dan Yusup (2011) berdasarkan penelitian yang dilakukan menunjukkan bahwa tingkat kesesuaian sistem manajemen mutu PT. MAK terhadap sistem manajemen mutu ISO 9001: 2008 berada pada tingkatan sesuai dengan tingkat kesesuaian 89,84\%. Dari hasil analisis kinerja diperoleh bahwa skor kinerja PT. MAK adalah 81,50\%, hal ini berada pada kategori baik. Koefisien determinasi sebesar 0,671 atau 67,1\%, berarti kinerja PT. MAK dipengaruhi secara bersama-sama oleh variabel material, man, machine, method, environment. Sisanya sebesar 32,9\% dipengaruhi oleh faktor lain di luar model regresi.

Karlinda (2013) melakukan penelitian yang bertujuan untuk melihat apakah Penerapan Sistem Manajemen Mutu ISO 9001:2008 mempunyai pengaruh yangpositif dan signifikan terhadap Kinerja Pegawai di KPPT Kabupaten Pemalang. Hasil penelitian menunjukkan bahwa ada pengaruh yang signifikan antara Penerapan Sistem Manajemen Mutu ISO 9001:2008 (X) yang terdiri dari dimensi Sumber Daya Manusia, Infrastruktur, dan Lingkungan Kerja terhadap Kinerja Pegawai (Y). Hal ini dibuktikan dengan hasil analisis KendallTau dan regresi ordinal. Hasilnya menunjukkan nilai z hitung lebih besar dari z tabel (3.555> 1.960). Dengan demikian, korelasi antara penerapan Sistem Manajemen Mutu ISO 9001:2008 dengan kinerja pegawai sebesar 0,544 $\mathrm{Hi}$ diterima.

Supriyadi (2012) dalam penelitian yang bertujuan untuk mengetahui sebesar besar pengaruh penerapan sistem manajemen mutu ISO 9001: 2008 terhadap kinerja guru di SMKN 1 Sedayu, Bantul. Hasil penelitian menunjukkan bahwa penerapan SMM ISO 9001: 2008 dipersepsi sangat baik, sedangkan 
kinerja guru dipersepsi sangat baik. Terdapat pengaruh yang positif dan signifikan antara SMM ISO 9001: 2008 terhadap kinerja guru.

Berdasarkan pemaparan berbagai hasil penelitian terdahulu dapat ditarik suatu benang merah bahwa penerapan sistem manajemen mutu ISO 9001: 2008 memiliki pengaruh yang baik terhadap kinerja karyawan. Hal ini sesuai dengan temuan dalam penelitian ini, meskipun terdapat beberapa aspek yang masih harus dibenani dan tingkatkan lagi pelayanannya. Evaluasi secara berkala penting untuk memberikan bahwa sistem jaminan mutu yang diterapkan mampu meningkatkan kualitas pelayanan pendidikan baik kepada mahasiswa, dosen, maupun tenaga kependidikan di lingkungan UIN Syarif Hidayatullah Jakarta.

\section{SIMPULAN}

Berdasarkan hasil yang ditemukan memperlihatkan bahwa terdapat pengaruh yang signifikan antara penerapan ISO 9001: 2008 terhadap kinerja karyawan UIN Syarif Hidayatullah Jakarta. Hal ini menunjukkan bahwa setelah penerapan ISO 9001: 2008 memiliki pengaruh terhadap peningkatan karyawan UIN Syarif Hidayatullah Jakarta pada tiga fakultas yang diteliti.

Dari sebaran kuesioner yang dilakukan terhadap mahasiswa, dari delapan dimensi ISO 9001: 2008 memiliki kategori baik. Mahasiswa menilai dalam penerapan ISO 9001: 2008 ini masih terjadi ketimpangan pelayanan dalam hal penerapannya. Tingkat kepuasan mahasiswa secara umum masih menyatakan kurang puas terhadap layanan yang diberikan oleh karyawan UIN Syarif Hidayatullah Jakarta.

\section{PUSTAKA ACUAN}

Arikunto, Suharsimi. 2006. Prosedur Penelitian; Suatu Pendekatan Praktik, edisi revisi VI. Jakarta: Rineka Cipta

Dharma, C. 2007. Analisis Pengaruh Penerapan Sistem Manajemen Mutu ISO 9001: 2000 Terhadap Peningkatan Kinerja Pada PT Jasa Raharja (Persero) Cabang Sumatera Utara. (Tesis Tidak Dipublikasikan). Medan: Universitas Sumatera Utara. 
Eriyanto. 2007. Teknik Sampilng; Analisis Opini Publik. Yogyakarta: LKIS Yogyakarta .

Gomes, F.C. 2000. Manajemen Sumber Daya Manusia. Yogyakarta: Penerbit Andi Offset.

Handoko, H. 2003. Manajemen Personalia Dan Sumber Daya Manusia, edisi Kedua. Yogyakarta: Penerbit BPFE-UGM.

Iriani, Y \& D. Hadiputra. 2010. Analisis Pengaruh Penerapan Sistem Manajemen Mutu ISO 9001: 2008 Terhadap Kinerja Karyawan Di PT Industri Telekomunikasi Indonesia. Simponasium Nasional RAPI IX 2010.

Karlinda, F. 2013. Pengaruh Penerapan Sistem Manajemen Mutu ISO 9001: 2008 Terhadap Kinerja Pelayanan Perijinan Terpadu Kabupaten Pemalang. (Skripsi Tidak Dipublikasikan). Purwokerto: Universitas Jenderal Soedirman.

Lestari, I. 2012. Pengaruh Sistem Penjaminan Mutu Internal dan Sistem Manajemen Mutu ISO 9001: 2008 Terhadap Kinerja UNIKA Atmajaya. (Tesis Tidak Dipublikasikan). Depok: FISIP Universitas Indonesia.

Mangkunegara, A.P. 2000. Manajemen Sumber Daya Manusia Perusahaan. Bandung: Penerbit Remaja Rosdakarya.

Mifriadi, Ade. 2006. Kajian Tentang Hubungan Penerapan Sistem Manajemen Kualitas ISO 9002 dan Kualitas Kehidupan Kerja Terhadap Produktivitas Karyawan: Studi Kasus di PT Austral Byna Divisi Industri, Banjarmasin, Kalimantan Selatan. (Tesis Tidak Dipublikasikan). Bogor: Institut Pertanian Bogor.

Nawawi, H.H. 1997. Manajemen Sumber Daya Manusia. Yogyakarta: Penerbit Gajah Mada University Press.

Riduwan \& Akdon. 2005. Rumus dan Data dalam Analisis Statistika. Bandung: Alfabeta.

Semuel, H. \& J. Zulkarnain. 2006. Pengaruh Sistem Manajemen Mutu ISO Terhadap Kinerja Karyawan Melalui Budaya Kualitas Perusahaan: Studi $\begin{array}{llll}\text { Kasus } & P T & \text { Otsuka } & \text { Indonesia }\end{array}$ http://repository.petra.ac.id/16144/1/ Publikasi1_94033_ 1006.pdf. diakses pada 2 Februari 2014. 
Silaban, B. E. \& S. Yusup. 2011. Implementasi Sistem Manajemen Mutu ISO 9001: 2008 Pada Industri Kontraktor: Studi Kasus PT. MAK. Esensi, Vol. 14, No. 3, Desember 2011. pp. 16 - 38

Singarimbun, M \& Effendi, S (Ed). 1989. Metode Penelitian Survai, edisi revisi. Jakarta: LP3ES

Singgih Santoso. 2009. Panduan Lengkap Menguasai Statistik dengan SPSS 17. Jakarta: Elex Media Komputindo.

Sugiyono. 2009. Metode Penelitian Pendidikan Pendekatan Kuantitatif, Kualitatif, dan R\&D. Bandung: Alfabeta.

Suryabrata, Sumadi. 2003. Metodologi Penelitian. Jakarta: Rajagrafindo Persada.

Walpole, R.E. 2005. Pengantar Statistika, edisi ke-3. Jakarta: Gramedia Pustaka Utama.

Willy, Susilo. 2003. Audit mutu Internal; panduan praktis para praktisi manajemen mutu dan auditor mutu internal. Jakarta: Vorqistatama binamega. 